Article

\title{
Emergy Evaluation of Dwelling Operation in Five Housing Units of Montreal Island, Canada
}

\author{
Ricardo Enrique Vega-Azamar ${ }^{1, *}$, Rabindranarth Romero-López ${ }^{2}$, \\ Norma Angélica Oropeza-García ${ }^{3}$, Mathias Glaus ${ }^{4}$, Robert Hausler ${ }^{4}$ and \\ Herlinda del Socorro Silva-Poot ${ }^{1}$ \\ 1 Tecnológico Nacional de México, Instituto Tecnológico de Chetumal; Insurgentes 330, \\ Col. David Gvo. Gutiérrez, Chetumal 77013, Quintana Roo, Mexico; hsilva@itchetumal.edu.mx \\ 2 Unidad de Investigación Especializada en Hidroinformática y Tecnología Ambiental, \\ Facultad de Ingeniería Civil, Universidad Veracruzana, Lomas del Estadio s/n, Zona Universitaria, \\ Xalapa 91000, Veracruz, Mexico; rabromero@uv.mx \\ 3 División de Ciencias e Ingeniería, Universidad de Quintana Roo, Boulevard Bahía s/n esquina Ignacio \\ Comonfort, Col. Del Bosque, Chetumal 77019, Quintana Roo, Mexico; noropeza@uqroo.edu.mx \\ 4 Station Expérimentale des Procédés Pilotes en Environnement, École de Technologie Supérieure, \\ Université du Québec, 1100, rue Notre-Dame Ouest Local A-1500, Montreal, QC H3C 1K3, Canada; \\ mathias.glaus@etsmtl.ca (M.G.); robert.hausler@etsmtl.ca (R.H.) \\ * Correspondence: revega@itchetumal.edu.mx; Tel.: +52-983-832-1019 (ext. 147) \\ Academic Editor: Tan Yigitcanlar \\ Received: 20 February 2017; Accepted: 18 April 2017; Published: 21 April 2017
}

\begin{abstract}
Sustainability of cities and the environmental implications of high resource utilization by the domestic sector are growing concerns related to urban regions. Well-informed urban planning decision-making is an essential tool to help in the task and, for that, an important point to consider is the influence of parameters like residential density and housing typology on the intensity of resource utilization. Emergy synthesis, a life-cycle energy analysis methodological approach that considers the interaction of natural and human-made flows, was used to evaluate the environmental support for dwelling operational stage in five typical present-day housing units on the island of Montreal. As expected, resource utilization, measured as total emergy used, was positively correlated to housing unit size both with respect to number of occupants and dwelling size. Results suggest that variables affecting notably the intensity of resource utilization are per household income and per dweller habitable space and, while a higher income increased per capita emergy in all cases, increasing space availability per resident did not result in a decrease of empower density after $50 \mathrm{~m}^{2} /$ person. Future work should consider lower and higher densities and analyses at the scale of blocks, neighborhoods and urban planning zones.
\end{abstract}

Keywords: housing unit; dwelling operation; housing type; resource utilization; emergy-based performance indicators

\section{Introduction}

Since the end of the last decade, most of the world's population resides in a city and around 33\% of city-dwellers lives in a slum [1]; current trends indicate that the number of urban residents will continue to increase to around $66 \%$ of total world population by 2050 [2]. Among the main local level to global scale environmental problems related to urban growth, often also associated with inadequate planning, are decline in agricultural and forest land, drying out of marshes, extraction of construction materials in large quantities, pollution of water courses by untreated wastewater, air pollution and large emissions of greenhouse gases from motor vehicles and industries [3,4]; hence, the evolution and development of cities has become a growing concern. 
The domestic sector's high resource consumption in urban regions is a frequent characteristic that must be undertaken. For instance, operation of buildings in urban areas requires a substantial fraction of the energy used in the world, reaching up to $50 \%, 41 \%$ and $36 \%$ in the UK, the EU and the USA, respectively [5], and fractions corresponding to the transport and industry sectors should also be added. Household domestic consumption is an important source of greenhouse gases (GHG) in urban areas, along with the industrial and urban agricultural sectors [6]. Food, people's mobility, and energy use at home are arguably three of the most important features related to housing activities threatening sustainability; altogether, they may be responsible of up to four-fifths of the environmental impacts in developed countries [7].

An important point to consider is the influence of the occupation intensity of the urban territory on resource consumption. Since almost three decades ago, Newman and Kenworthy [8] in their seminal work, found that cities with low population density use more energy for the transportation of people than cities with higher occupation rates. In the case of residential land uses, occupation intensity is directly determined by development density (number of dwellings per unit area), but it also involves concepts like spatial distribution of dwellings, housing typology, dwelling occupation rate $[9,10]$ and other features indirectly related to urban form, such as distance to downtown and access to urban amenities and infrastructure [11].

The operational stage of buildings is a very important phase of their life cycle. Some authors have found that energy consumption in the operation of residential buildings may account for up to $90 \%$ of total energy consumption in the life cycle of that kind of buildings [12]; while other authors have found housing type, floor area, occupancy rate and household income among other variables influencing electricity consumption during the operational stage of residential buildings [13].

For their part, material flow accounting [14,15], ecological footprint [16,17], and life cycle energy analysis $[10,18,19]$ are among the most widely used methodologies to quantify the flows that coincide in the built environment. Emergy synthesis belongs to the energetic life cycle approach, but it also allows the integration of both natural and human-made flows (like the economic ones) into the same basis of comparison, which takes into consideration the 'free' services provided by the environment and their quality: "emergy is the total amount of available energy of one kind (usually solar) that is directly and indirectly required to make a given product or to support a given flow" [20].

Emergy analysis has showed to be an appropriated methodology to evaluate and compare sustainability in the built environment because it allows to consider, in a combined way, the flows of different nature intertwining in urban ecosystems [21]. From the standpoint of geographical disaggregation level, emergy synthesis has been used in several studies from the urban region scale to the building level scale. At the city scale, several works have been reported since one of the seminal works was published in 1998 for the Taipei region [22], among which are studies for Rome [23], Macao [24], Beijing [25] and Montreal [26], just to cite some of them.

At the building level, several emergy assessments have been carried out focusing on the environmental impact of construction materials and on energy efficiency of single buildings $[27,28]$ or addressing the subject from a generic perspective, since building appraisal was not the central issue of the study [29]. At this scale of analysis, other methodological tools have been combined with emergy synthesis; arguably, the most widely used in this way is life-cycle assessment since Hau and Bakshi noticed the advantages this might entail [30]. With this methodological combination, Reza et al. compared a single-family building with a multi-family building in Canada [31] and evaluated the sustainability of paved roads [32], and Li and Wang assessed a residential area of more than 150,000 inhabitants although with a building level approach [33], just to mention a few. The common denominator of these studies is that the focus is mainly on building materials and construction processes' environmental performance and on the environmental impacts of single buildings (for the case of dwelling buildings), in which the operational stage does not include the dwellers daily activities; in general, for this stage of the building life cycle, the main variables considered are water 
and energy consumption, which are estimated either through average statistical values or well-known simulation tools.

On the other hand, from the urban planning perspective, a relevant intervention level is the neighborhood [34]. At this disaggregation level, or close to it, some authors have highlighted the need for information at the scale of land use or land cover to determine the relationship between socioeconomic performance of urban subsystems such as industry, business and commerce, real estate and housing developments and other services and their environmental implications [35]. Also, regarding environmental sustainability, some studies have pointed out the need of studying quantitatively, and in greater detail, the impacts that go beyond the neighborhood limits, including regional resource use, due to the fact that local consumption of goods and services is greatly dependent on areas surpassing the city level [36].

A relevant scale of analysis between the building level and the neighborhood or planning zone level (e.g., residential land use) is the housing unit, which is an essential part of the neighborhood structure. To a large extent, for the case of the residential land use, urban form is induced through the application of density, and other related parameters, to groups of blocks, which translates into different housing unit configurations. This study aimed at providing elements to close the gap in this opportunity area for sustainable urban development and planning; it was conducted with a strong sustainability approach [37], focusing on the environmental work provided by the resources supporting dwelling operational stage in the housing units, since this phase is one of the most important of the whole dwelling life cycle. At this stage, not only direct dwelling operation related activities (e.g., water and energy consumption) should be taken into account: dwellers activities (e.g., food, mobility, goods and services) are also relevant for the appraisal of the way in which housing units use resources, in this case, through the quantification of emergy-based sustainability indicators.

In this context, the present work sought to quantify the environmental support required for dwellers' daily activities in five housing units on the island of Montreal, Canada $\left(45^{\circ} 30^{\prime} \mathrm{N}, 73^{\circ} 30^{\prime} \mathrm{W}\right)$. In 2015 , the Island had a total population of two million inhabitants distributed in an area of $500 \mathrm{~km}^{2}$ [38]. The economy of the Island is based on industrial, technology and knowledge related activities [39]. Net residential density (total number of dwellings divided by lot area without roads and public and institutional related infrastructure) averages 38.5 dwellings per hectare ( $\mathrm{dw} / \mathrm{ha})$ on the island, ranging from around $120 \mathrm{dw} /$ ha in downtown districts to $15 \mathrm{dw} /$ ha in suburban residential areas [40]. The general objective of the study was to evaluate the 'free' environmental work supporting dwelling operational stage using five typical present-day housing units in Montreal Island as a case study by means of the appraisal of the main flows interacting in the residential units with the help of the emergy environmental accounting methodology to examine the usefulness of emergy-based indicators for assisting urban planning decisions, especially, in the setting-up of future residential units' environmental design guidelines to support neighborhood planning processes.

The work has a sustainable urbanism perspective, since the focus is put on the applicability of sustainability criteria (emergy-based indicators) to support decision-making in urban planning contexts. As already mentioned, the work's main purpose was to explore the appropriateness of using sustainability indicators as a complement of commonly used parameters in urban physical planning decision-making (e.g., development density, building parameters, accessibility to urban amenities), to collaborate in the setting-up of guidelines for housing units and neighborhoods with better environmental performance. Among the emergy-based indicators calculated for the dwelling operational stage in the five selected housing units (all of which are described in greater detail in the methods, results and discussion sections) are per capita emergy use, indicating resource use intensity on a per dweller basis, empower density, indicating resource use intensity per unit area, and emergy to money ratio, indicating ecological-economic efficiency. It was observed that overall resource utilization (total emergy used) was positively correlated to housing unit size (both with respect to number of occupants and to floor area) and it was also noticed that per household income and per dweller habitable space influenced intensity of resource utilization in the analyzed housing units. 


\section{Methods and Data}

\subsection{Emergy Synthesis}

An important aspect that should be considered in life-cycle energy studies is that there are different energy qualities organized in a hierarchy; for example, many joules of sunlight are required to generate one joule of electricity [20]. Here, a central idea is the required amount of accumulated energy at the input of a process to obtain one joule, one gram or one dollar at its output, the emergy unit value concept; when this value relates the accumulated energy (measured in seJ, solar emergy joules) in the input to the energy obtained (available) at the output (joules) of a process, it is known as transformity, which is the most widely known emergy unit value and it is also a measure of the energy efficiency of the process [41].

Initially, a balance of the energy accumulated in the biosphere was made [42,43]. Subsequently, from the aforementioned energy balance, transformities of large ecosystems such as forests, marine and wetland ecosystems, agricultural landscapes and lakes were calculated [44-46]. Likewise, from these transformities, unit values of resources such as wood, soil, water, among others, were estimated, and so on; emergy unit values of human-made materials, products and services have been calculated with a very good level of detail and are available for their use in studies of different academic disciplines [21,23].

Generally, emergy assessments start with the delimitation of the system under analysis (Figure 1). The system's diagram should include the most important flows of materials, energy, money, etc. at the input and output. For the evaluation of the housing units, the most important natural flows considered were: energy from the sun, wind kinetic energy, loss of vegetation humidity (evapotranspiration), loss of surface soil, food, water, domestic consumer goods, electricity, fuels, municipal solid wastes and wastewater. Once the system under analysis is delimited, a table is drawn up with the raw data collected and processed to calculate the emergy flows (Table 1), which are computed by multiplying the first ones by the appropriate emergy unit values [41].

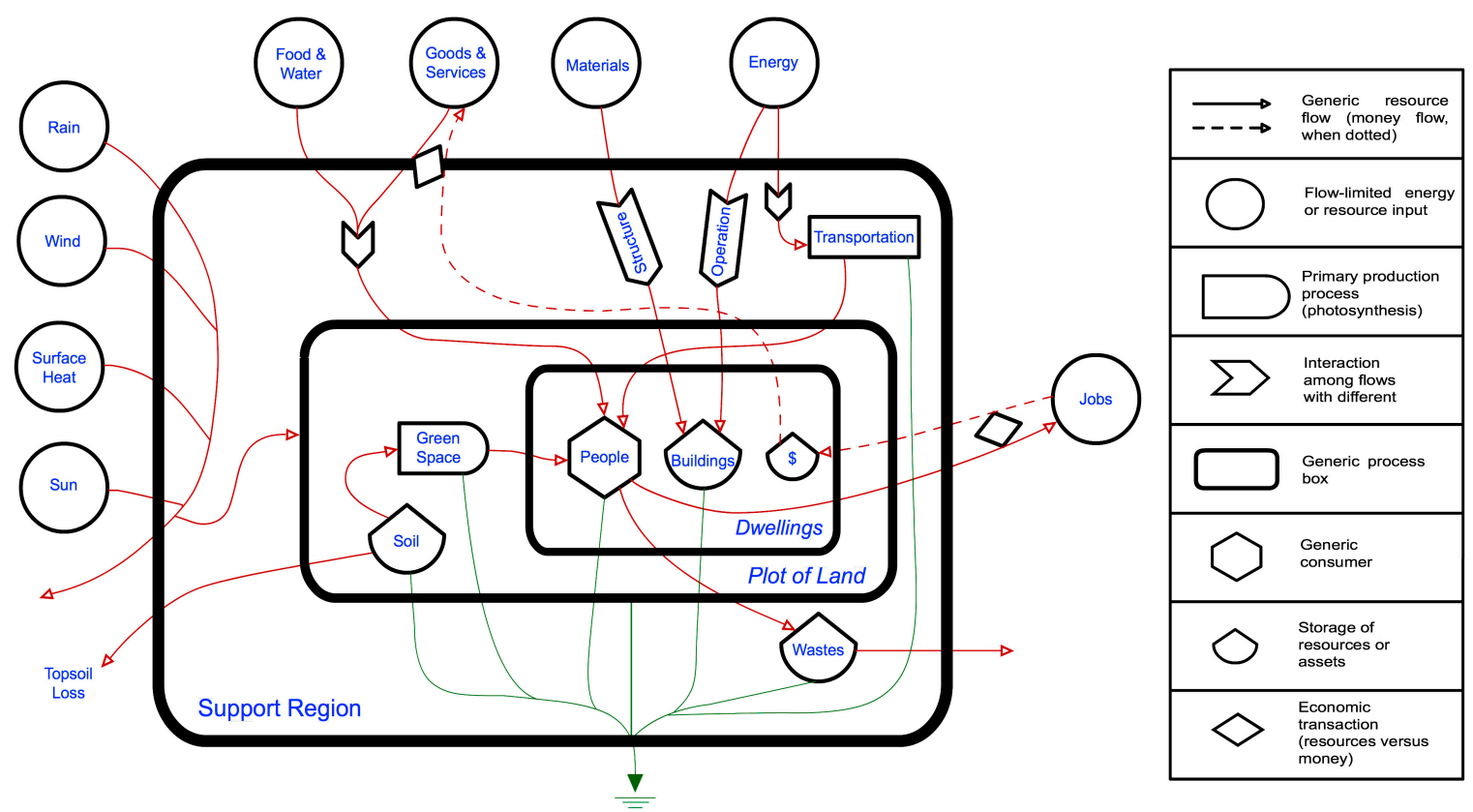

Figure 1. Diagram of the flows considered in the selected housing units.

In the present study, the only feature not corresponding to dwelling operational stage considered was the building materials in the structure; it was examined to explore the approximate percentage they represent of total emergy used. Although other materials present in dwellings, like non-structural 
materials and finishes, and related infrastructure, such as streets, sewers and other facilities, are important components contributing to total emergy used, they were not considered in this work because, unlike structural materials, they are present in similar proportions in virtually all cases, and maintenance and other constructive stages appear to have low significance [18] and, for its part, the structure may represent up to $80 \%$ of the bulk of a typical construction [47]. Likewise, the distance to downtown was taken into account as an important parameter affecting resource consumption owing to residents' mobility, which in turn should be considered as a dwelling operational stage inherent activity [48].

Total emergy utilized $(U)$ is the sum of the emergy from purchased goods (items 5 to 21 in Table 1) and the highest value of emergy from renewable resources (items 1 to 4 in Table 1), to avoid double counting [25,49]. The global baseline of emergy accumulated in the biosphere considered in the present study was $15.83 \times 10^{24} \mathrm{seJ} /$ year, which was estimated from solar insolation, deep earth heat and tidal energy [41,43]. Once the aggregate emergy flows are calculated, i.e., renewable $(R)$, non-renewable $(N)$, acquired or purchased $(F)$ and those accumulated in wastes $(W)$, the performance of the system under study is evaluated through indicators and indices (Table 2), which are used as support criteria in decision-making processes [50].

Table 1. Emergy synthesis of the analyzed flows in the housing units (Outremont's case).

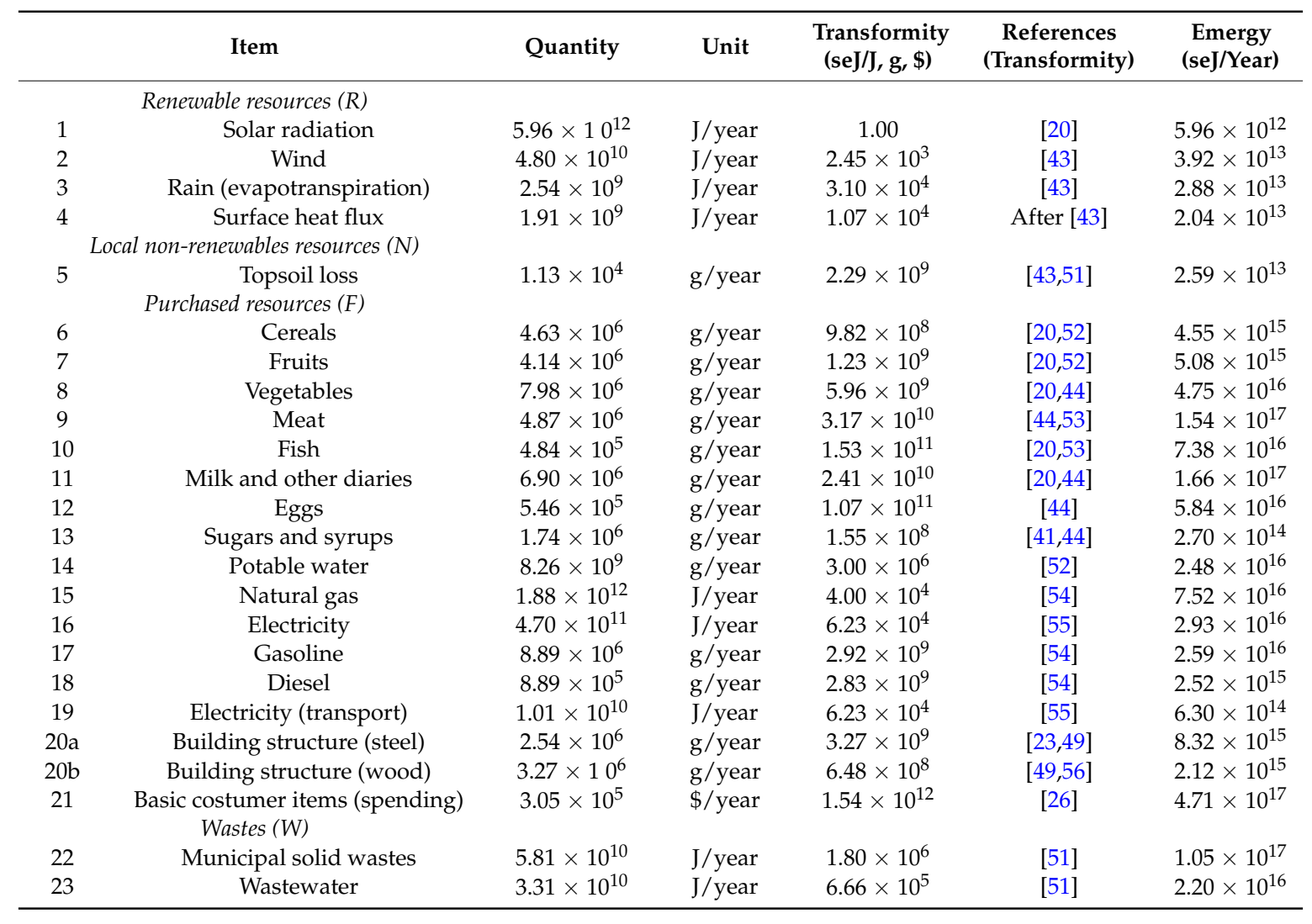

The above-mentioned indicators help to compare the performance of the considered housing units with an emphasis on the environmental support (measured as emergy from the used goods and services) needed for the households' daily running.

For further methodological issues related to emergy analysis, the following references may be consulted [20,41,43-46,50,57,58]. For case studies of emergy synthesis in the built environment, the following papers may also be consulted [23-28,33,51]. 
Table 2. Emergy-based indicators calculated for the case studies.

\begin{tabular}{|c|c|c|c|}
\hline Indicator & Calculation & Unit & Indication \\
\hline Per capita emergy $\left(U_{c a p}\right)$ & $U /$ number of residents in the residential unit & seJ/person $\cdot$ year & Standard of living \\
\hline Empower per household $(E H)$ & $U /$ number of dwellings in the residential unit & seJ/household.year & Living quality \\
\hline Emergy to money ratio (EMR) & $U /$ total income of the residential unit & $\mathrm{seJ} / \mathrm{USD}$ & $\begin{array}{c}\text { Ecological } \\
\text { economic efficiency }\end{array}$ \\
\hline Per capita support area $\left(S A_{\text {cap }}\right)$ & $\begin{array}{l}\left([N+F] /[E L R \times(R / \text { area })]_{\text {Montreal }}\right) / \text { number of } \\
\text { residents in the residential unit }\end{array}$ & $\mathrm{m}^{2} /$ person & $\begin{array}{l}\text { Emergy-based } \\
\text { ecological footprint }\end{array}$ \\
\hline Per household emergy of wastes $(W H)$ & $W /$ number of dwellings in the residential unit & seJ/household.year & Environmental loading \\
\hline
\end{tabular}

\subsection{Data}

Five residential units, located in five different boroughs of the City of Montreal, were analyzed. The housing types of the units were: four-story apartment buildings, two and three-story side attached townhouses and three-story complexes in the unit in the borough of Rosemont, two-story side attached small houses and four-story multifamily buildings in Outremont, three-story multifamily building in Plateau Mont-Royal (M-R), seven-story multifamily building in Saint-Laurent and five-story multifamily building in Saint-Leonard, with lot coverage ratios of $42,80 \%, 52 \%, 28 \%$ and $50 \%$, respectively [59]. Distance to the city center was estimated indirectly through the length between the location of the residential units and the center of the central business district of the island, which was measured with the help of ArcView 3.3 GIS software. As mentioned above, distance to downtown was estimated as a straight line (rather than network distance) as a proxy to explore the importance of occupants' mobility on daily resource consumption as the analysis was focused on household day-by-day activities. Tables 3 and 4 show the most relevant features used in the assessment of the residential units.

Table 3. Main features of the housing units.

\begin{tabular}{ccccccc}
\hline Case & $\begin{array}{c}\text { Net Density } \\
\text { (dw/ha) }\end{array}$ & $\begin{array}{c}\text { Year of } \\
\text { Occupation }\end{array}$ & $\begin{array}{c}\text { Number of } \\
\text { Dwellings }\end{array}$ & $\begin{array}{c}\text { Number of } \\
\text { Residents }\end{array}$ & $\begin{array}{c}\text { Structure's } \\
\text { Material }\end{array}$ & $\begin{array}{c}\text { Distance to } \\
\text { DT (km) }\end{array}$ \\
\hline Rosemont & 85 & $1997-2000$ & 217 & 510 & Concrete/Wood & 7.0 \\
Outremont & 171 & 2001 & 23 & 48 & Steel/Wood & 4.9 \\
Plateau M-R & 180 & 2006 & 36 & 89 & Wood & 2.3 \\
Saint-Laurent & 271 & 2007 & 83 & 208 & Concrete & 7.7 \\
Saint-Léonard & 323 & 2005 & 47 & 94 & Concrete & 7.9 \\
\hline
\end{tabular}

Table 4. Housing typologies of the residential units.

\begin{tabular}{ccccc}
\hline Case & Housing Typology & $\begin{array}{c}\text { Number of } \\
\text { Bedrooms }\end{array}$ & $\begin{array}{c}\text { Avg. Habitable } \\
\text { Area }\left(\mathbf{m}^{2} / \mathbf{d w}\right)\end{array}$ & $\begin{array}{c}\text { Avg. Occupants } \\
\text { Per Dwelling }\end{array}$ \\
\hline Rosemont & $\begin{array}{c}\text { Low-rise apartment buildings, side } \\
\text { attached houses and triplexes }\end{array}$ & 1 to 6 & 114.0 & 2.35 \\
\hline Outremont & $\begin{array}{c}\text { Side attached small houses, low-rise } \\
\text { big apartment buildings }\end{array}$ & 1 to 6 & 116.1 & 2.10 \\
\hline Plateau M-R & Low-rise apartment buildings & 1 to 4 & 84.5 & 2.50 \\
\hline Saint-Laurent & Mid-rise apartment buildings & 1 to 4 & 59.1 & 2.50 \\
\hline Saint-Leonard & Mid-rise apartment buildings & 1 to 5 & 58.5 & 2.00 \\
\hline
\end{tabular}

The year of study was 2008, however, some information came from sources of slightly different dates, such as the studies related to energy consumption in buildings, the electoral districts statistics profiles, given that all data were scaled down to the most detailed level of disaggregation possible as one of the highest priorities and challenges [34]. 
In addition, unavailable data for the year of study, especially those belonging to money flows (all expressed in U.S. dollars), were converted to 2008's value through the application of price indexes $[18,60]$. Table 5 shows the data processing.

Table 5. Data processing.

\begin{tabular}{clc}
\hline Item & \multicolumn{1}{c}{ Processing } & References \\
\hline Natural resources & \multicolumn{1}{c}{ Long period averages } & {$[61-63]$} \\
\hline Food & $\begin{array}{l}\text { Per capita averages for Canadian cities adjusted by food spending and per } \\
\text { household income in electoral districts }\end{array}$ & {$[64-66]$} \\
\hline Water & Per capita treated drinking water adjusted by consumption by house type & {$[67,68]$} \\
\hline Energy from dwelling operations & Energy consumption by house type & {$[69-72]$} \\
\hline Energy from transport & Calculated from the metropolitan survey of people's mobility & {$[34,73-75]$} \\
\hline Building materials in the structure & Materials take-off estimation & {$[76-79]$} \\
\hline Basic consumer items & Household expenditure in boroughs adjusted by electoral districts' per & {$[65,66]$} \\
\hline Municipal solid wastes & Pousehold income & {$[80]$} \\
\hline Wastewater & Per capita generation of municipal solid wastes in boroughs & {$[67,68,81]$} \\
\hline
\end{tabular}

\section{Results}

Total emergy utilized $(U)$ changed in correspondence with housing unit size, both with respect to dwelling occupancy and building size, as anticipated, and purchased emergy $(F)$ was the dominant flow sustaining dwelling operation and dwellers day-by-day activities.

\subsection{Aggregated Emergy Flows}

Purchased emergy $(F)$ averaged $99.99 \%$ of total emergy used, while renewable emergy $(R)$, local non-renewable emergy $(N)$ and emergy from wastes $(W)$ averaged about $0.0074 \%, 0.0026 \%$ and $15.11 \%$ of $U$, respectively. Table 6 shows the main emergy flows computed for the five housing units. Due to the statistical limitations of the present study, and to the level of data disaggregation, the presented figures may not be significant, but they can lead to interesting traces, especially in urban contexts [82]: the presented figures, especially those relating to natural flows, should be considered with absolute caution.

Table 6. Total emergy used $(U)$ and emergy flows (as \% of $U$ ) in the housing units.

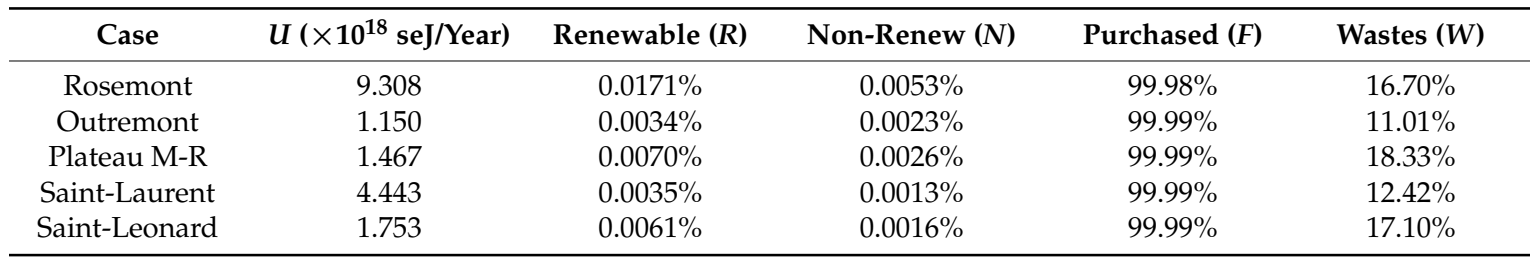

$R$ corresponded to the kinetic energy from wind for the housing unit in Outremont borough, where lot coverage ratio was the highest $(80 \%)$, and to the chemical potential of rain (evapotranspiration in green areas) for the rest of the cases, while $N$ corresponded to topsoil loss for the setting-up of the housing units.

\subsection{Purchased Emergy and Emergy From Wastes}

In the five housing units, both per dweller and per unit of floor area, emergy consumptions were determined, in both cases, the higher the $U_{c a p}$ and the $E D_{H a b}$, the higher the intensity of resource use. Figure 2 shows the itemized flows that were analyzed in the five residential units.

Emergy from food and water accounted for just over $50 \%$ of $U$ in the housing units; the units in Saint-Laurent and in Saint-Leonard presented the largest and smallest per resident uses $\left(12,143 \times 10^{12}\right.$ 
and $9700 \times 10^{12} \mathrm{seJ} /$ person.year, respectively) and the units in Saint-Laurent and in Outremont presented the highest and the lowest emergy consumption values per unit area $\left(515 \times 10^{12}\right.$ and $200 \times 10^{12} \mathrm{seJ} / \mathrm{m}^{2} \cdot$ year, respectively).

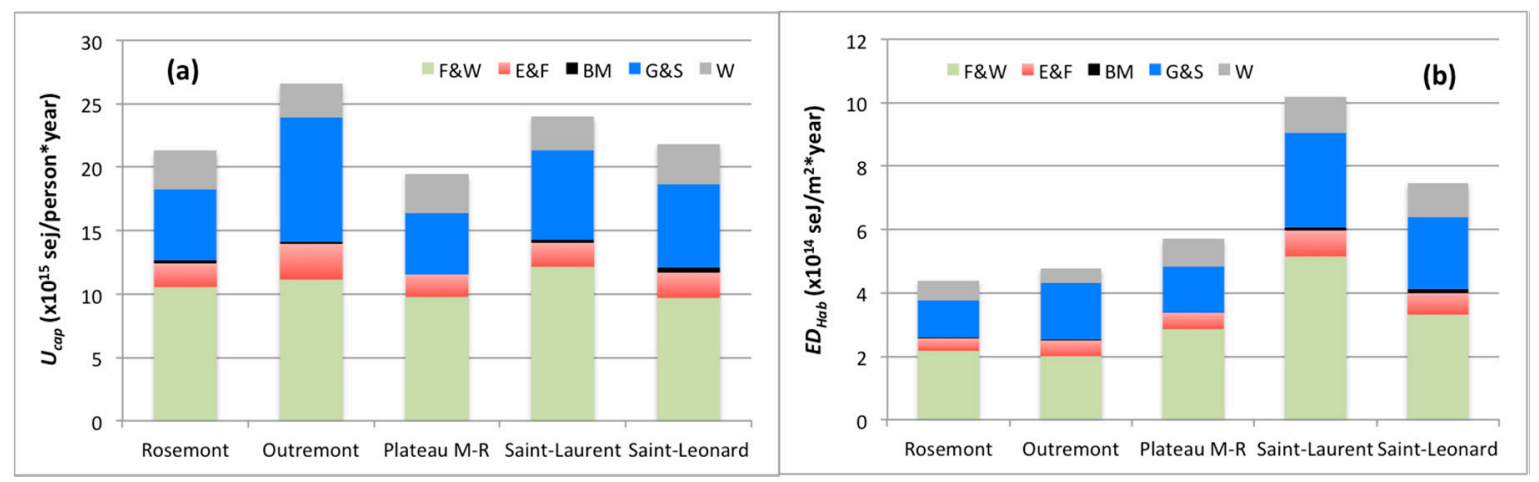

Figure 2. Emergy requirements of the five residential units: (a) on a per capita basis, and (b) per square meter of habitable space. F\&W: food and water; E\&F: electricity and fuels; BM: building materials in the structure; G\&S: basic goods and services acquired; W: wastes.

Emergy from basic consumer items and services accounted for nearly $34 \%$ of $U$ in the housing units; Outremont exhibited the highest per capita use $\left(9819 \times 10^{12} \mathrm{seJ} /\right.$ person $\cdot$ year $)$ and Plateau Mont-Royal the lowest $\left(4900 \times 10^{12} \mathrm{seJ} /\right.$ person-year) and Saint-Laurent and Rosemont showed the largest and the smallest consumptions per unit area $\left(300 \times 10^{12}\right.$ and $115 \times 10^{12} \mathrm{seJ} / \mathrm{m}^{2} \cdot$ year, respectively).

In all five cases, emergy from energy for both dwelling operation and dwellers mobility, averaged $10 \%$ of $U$ in the housing units; Outremont presented the highest per occupant use $\left(2783 \times 10^{12} \mathrm{seJ} /\right.$ person $\left.\cdot y e a r\right)$ and Plateau Mont-Royal the lowest $\left(1753 \times 10^{12} \mathrm{seJ} /\right.$ person $\left.\cdot y e a r\right)$, while, once again, Saint-Laurent and Rosemont presented the largest and the smallest consumptions per unit area $\left(81 \times 10^{12}\right.$ and $39 \times 10^{12} \mathrm{seJ} / \mathrm{m}^{2} \cdot$ year, respectively).

As mentioned above (Table 5), the highest percentage of emergy from generated wastes corresponded to the unit in Plateau M-R; the highest per resident emergy from wastes corresponded to the unit in Saint-Leonard $\left(3190 \times 10^{12} \mathrm{seJ} /\right.$ person-year $)$ and the highest per floor area value corresponded to that in Saint-Laurent $\left(113 \times 10^{12} \mathrm{seJ} / \mathrm{m}^{2} \cdot\right.$ year $)$, while the lowest per capita amount corresponded to the unit in Saint-Laurent $\left(2654 \times 10^{12} \mathrm{seJ} /\right.$ person-year $)$ and the lowest per square meter of habitable area value corresponded to that in Outremont $\left(47 \times 10^{12} \mathrm{seJ} / \mathrm{m}^{2}\right.$.year $)$.

The contribution of the structural components of the buildings was not significant in terms of emergy utilization when compared to the other analyzed flows; it only averaged $1.2 \%$ of $U$ in the housing units. The highest percentage corresponded to the unit in Saint-Leonard (2\%), which structure is made out of concrete, and the lowest to that in Plateau M-R $(0.3 \%)$, which structure is made out of wood. This trend did not vary when the basis of comparison was changed (per capita or per square meter) and, when concrete and steel were combined with wood (Rosemont and Outremont, respectively), emergy from the structure decreased markedly. Finally, Table 7 condenses the main emergy-based indicators calculated the five residential units.

Table 7. Emergy indicators estimated for the housing units.

\begin{tabular}{cccccccc}
\hline Housing Unit & $\boldsymbol{U}_{\text {cap }}$ & $\boldsymbol{E H}$ & $\boldsymbol{E D}_{\boldsymbol{H a b}}$ & $\boldsymbol{E M R}$ & $\boldsymbol{E L R}$ & $\boldsymbol{S A}_{\text {cap }}$ & $\boldsymbol{W H}$ \\
\hline Rosemont & $1.83 \times 10^{16}$ & $4.29 \times 10^{16}$ & $3.76 \times 10^{14}$ & $1.07 \times 10^{12}$ & 5864 & 81.58 & $7.16 \times 10^{15}$ \\
Outremont & $2.40 \times 10^{16}$ & $5.00 \times 10^{16}$ & $4.31 \times 10^{14}$ & $6.48 \times 10^{11}$ & 29321 & 107.13 & $5.51 \times 10^{15}$ \\
Plateau M-R & $1.65 \times 10^{16}$ & $4.07 \times 10^{16}$ & $4.82 \times 10^{14}$ & $1.03 \times 10^{12}$ & 14317 & 73.68 & $7.47 \times 10^{15}$ \\
Saint-Laurent & $2.14 \times 10^{16}$ & $5.35 \times 10^{16}$ & $9.06 \times 10^{14}$ & $8.75 \times 10^{11}$ & 28913 & 95.49 & $6.65 \times 10^{15}$ \\
Saint-Leonard & $1.87 \times 10^{16}$ & $3.73 \times 10^{16}$ & $6.38 \times 10^{14}$ & $9.03 \times 10^{11}$ & 16431 & 83.39 & $6.38 \times 10^{15}$ \\
\hline
\end{tabular}




\section{Discussion}

\subsection{Net Density and Distance to City Center}

Density of occupation is one of the most important features determining urban form, which is why many studies consider this parameter among the variables to analyze [9]. In this regard, net density of the residential units did not seem to influence per capita emergy use corresponding to energy for dwelling operation (including that for dwellers mobility), while it appeared to slightly affect per square meter use (Figure 3).
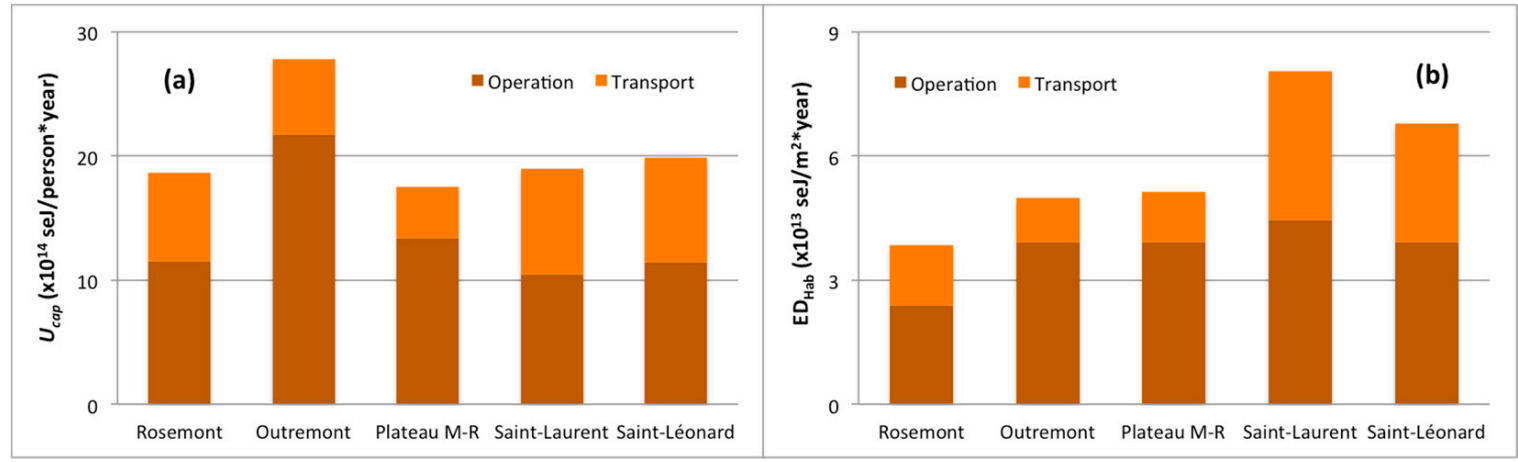

Figure 3. Emergy from dwellings operation and from dwellers transport: (a) on a per capita basis, and (b) by square meter of habitable area.

With respect to the emergy needed for dwelling operation of the housing units, with the exception of the unit in Outremont, outcomes on a per dweller basis show disparities with respect to findings of other similar studies in which energy use for building operation in low-density zones is 1.5 times higher, or more, than that in high-density areas [10,18], while per unit area results did not differ significantly. This may be attributed to the particular characteristics of the selected housing units (net density, dwelling typology and dwelling occupancy) and to differences in the mixing of electricity (in Montreal, its origin is hydraulic) and fuels considered in the present study.

Emergy from energy for the mobility of dwellers is more affected by distance to the city center than other variables like density (Figure 3), in a like manner to other works, which have found that distance to the core of the inner city is more relevant than parameters like housing typology, density and spatial arrangement of roads [11]. The units in Saint-Laurent and Saint-Leonard exhibited the highest values both on a per capita basis and per square meter of built-up area; both are the most distant to the city center (Table 3) and have the highest car use split, 66.5\% and 65.7\% respectively [73]. The relatively high and low consumption of the units in Rosemont and Plateau M-R may also be explained by the combination of distance to downtown and automobile mode split (48.1\% and 33\%, respectively).

\subsection{Per household Income and Available Space Per Person}

Total emergy use per dwelling $(E H)$ can be considered as proxy for living quality in the built environment [33], in this case the housing units, and, in the same way, per dweller emergy can also be taken as proxy for standard of living. Because of this, it was examined whether an equivalent economic indicator at the 'micro' level, per household income, could be associated to per dweller emergy utilization and to emergy use per dwelling, presuming that income levels vary in accordance to $U_{\text {cap }}$ and $E H$. This general trend was found, although more markedly for the two units with higher incomes, since the other three units have nearly equal incomes (Figure 4a).

It was also observed that increasing per dweller space availability, which occurs frequently as a result of the decrease of both housing density and accommodation of occupants by dwelling, decreases resource utilization intensity, measured as empower density of the living space, but up to some point: 
from around more than $50 \mathrm{~m}^{2}$ /person, increasing per resident space availability did not result in a decrease of $E D_{\mathrm{Hab}}$ (Figure $4 \mathrm{~b}$ ). Empower density is the total emergy used in a given area (in this case, the habitable area) per unit time; as mentioned above, it is an indicator of resource use intensity with high values for industrial activities and urban centers [83]; it may also may indicate scarcity of available land or need of support land [23]. $U_{c a p}, E H$ and $E D_{H a b}$ may also evidence 'abuse' of resource consumption, depending on the origin of the emergy flows.

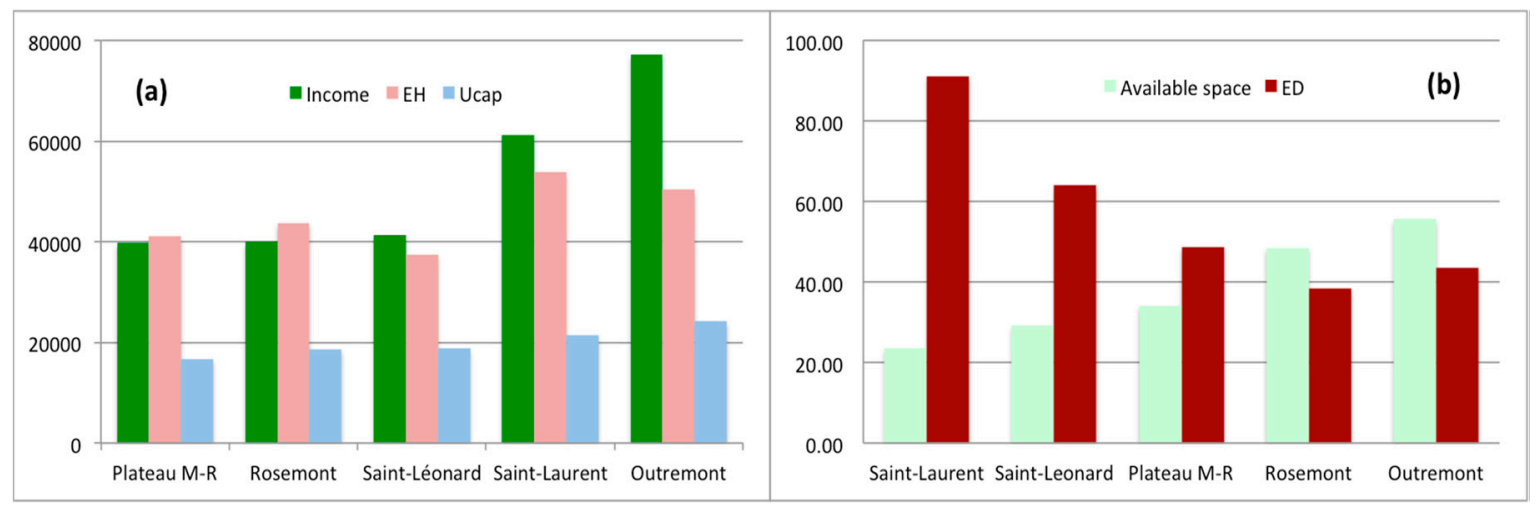

Figure 4. (a) Per household income (USD/year), emergy use per dweller $\left(\times 10^{12} \mathrm{seJ} /\right.$ household.year $)$ and per dweller emergy $\left(\times 10^{12} \mathrm{seJ} /\right.$ person.year $)$, and $(\mathbf{b})$ Per capita available space $\left(\mathrm{m}^{2} /\right.$ person $)$ and empower density of the habitable space $\left(\times 10^{13} \mathrm{seJ} / \mathrm{m}^{2} \cdot\right.$ year $)$.

\subsection{Emergy-Based Performance Indicators}

As mentioned in Table 2, ELR is the ratio of non-renewable and purchased emergy to renewable emergy, it evaluates the balance between non-renewable and renewable resources, so the higher its value, the less sustainable the system under study [83]. On the other hand, EMR illustrates the capacity of money to buy emergy [25], but it also can be taken as a proxy for economic-ecological efficiency: higher values of the emergy to money ratio are associated to lower levels of resource utilization efficiency [84]. In turn, carrying capacity can be calculated through the surface of land needed (SA) to acquire sufficient inputs to satisfy the resource demands of a population (in this case, the housing units' residents) circumscribed to a local system (Montreal Island), based on the regional system's level of development, specifically through its ELR [83].

With respect to these indicators, given that for each one of them lower values correspond to better performances, in addition to their individual values (displayed in Figure 5), the simultaneous performance of the three indicators can be appreciated by taking into account the combined surface of the three bars of each housing unit. Rosemont presented the lowest $E L R$, which may be explained by the contribution of renewable resources coming from green areas and by the habitable area to lot area ratio (the lowest). Outremont showed the lowest $E M R$, where the high-income level translates into a high emergy utilization rate. The relatively low per capita and per household emergy use in Plateau M-R is reflected in a smaller need of per dweller support area. The best-combined performance corresponded to the housing unit in Rosemont.

As mentioned above, per household empower may inform on living quality in housing areas. For its part, emergy from the wastes generated in the housing units (here, municipal solid wastes and wastewater) divided by the total number of households in each unit is an indicator of their environmental load. High values of $E H$ correspond to higher availability of resources, whereas high values of WH indicate greater impacts. In Figure 6, $E H$ to $W H$ ratios obtained for the residential units are plotted; these ratios may assist for assigning a sustainability ranking: in the graphic, a higher slope indicates a larger proportion of acquired commodities and services to generated pollutants [33]. In the studied units, the ranking, in descending order, was: Outremont, Saint-Laurent, Rosemont, Saint-Leonard and Plateau Mont-Royal. Higher household incomes in Outremont and Saint-Laurent 
units, which give them a greater ability to acquire emergy, do not seem to translate into a markedly greater amount of per household emergy from wastes.

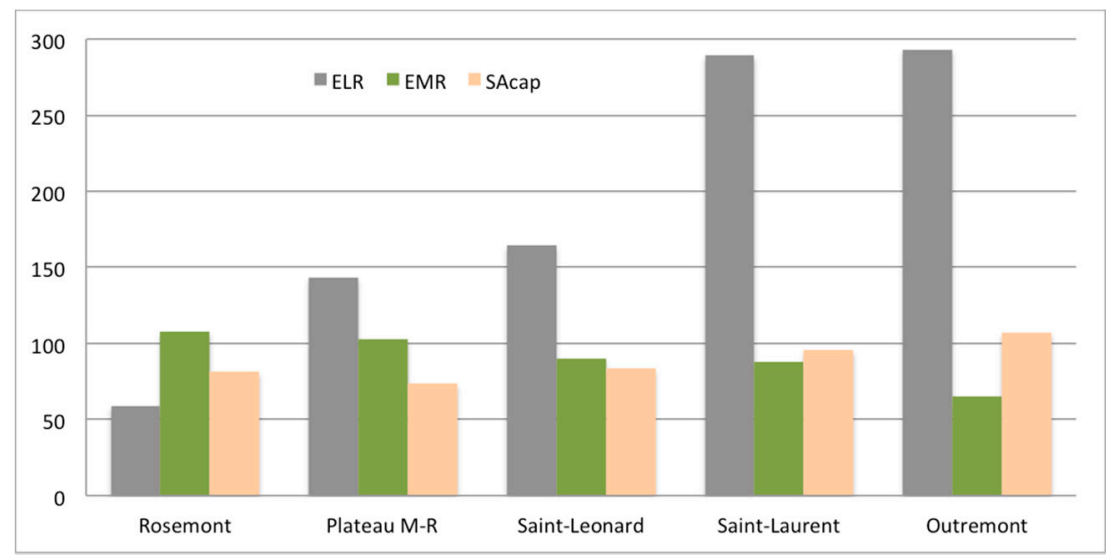

Figure 5. Environmental loading ratio $\left(\times 10^{2}\right.$, dimensionless), emergy to money ratio $\left(\times 10^{10} \mathrm{seJ} / \mathrm{USD} \cdot \mathrm{year}\right)$ and per dweller support area $\left(\mathrm{m}^{2} /\right.$ person) for the five residential units.

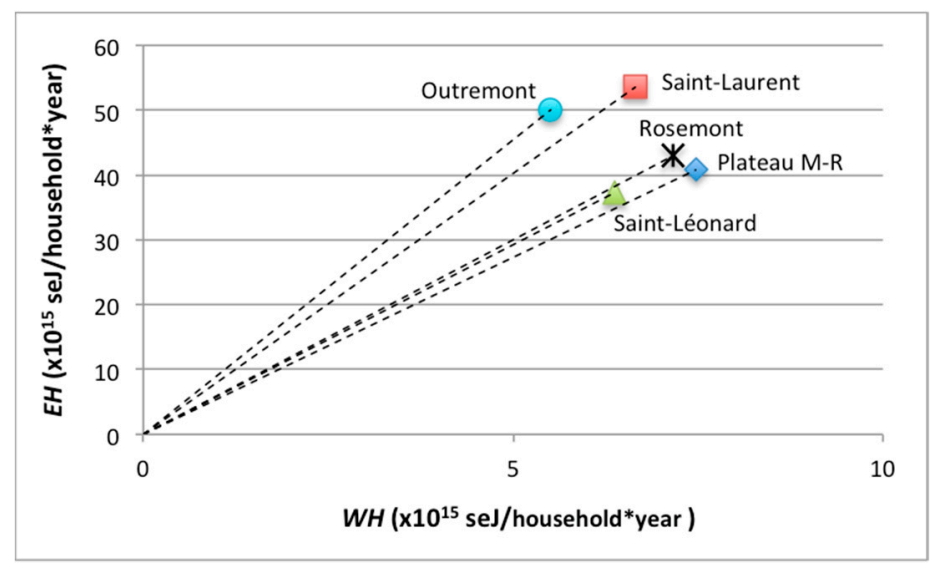

Figure 6. Per household empower per household and per household emergy from wastes.

\section{Conclusions}

We emphasize the exploratory nature of the present work; limitations of this kind of case studies are widely recognized. However, despite the strict lack of statistical representativeness, it is possible to pull interesting findings out, which become the basis for future research avenues.

The general aim of the study was to evaluate the environmental work supporting day-by-day activities in housing units by means of the emergy synthesis method. As expected, total emergy used, and the associated total emergy-based ecological footprint, is a function of housing unit size both with respect to number of occupants and to built-up area.

For all the itemized flows analyzed (with the exception of wastes and building materials in the structure) the largest per dweller emergy utilizations were associated to the housing units with the highest income levels. Also, the highest emergy use per unit floor area was always related to the dwelling unit with the smallest per capita space availability, and the lowest emergy utilizations per square meter of habitable area corresponded to the units with the lowest net housing densities.

With regard to emergy from wastes, on a per capita basis, greater amounts generated coincided with lower per household incomes in the analyzed residential units. This trend was confirmed when the ratio of per household emergy from wastes to per household empower was examined; the best efficiencies were found for high-income housing units. 
Although the contribution of the structural components of the analyzed buildings was no significant in terms of emergy utilization, it was found that concrete was the material with the highest emergy by square meter of constructed area, despite having an intermediate transformity (when compared to wood and steel). Notably, when concrete and steel were combined with wood, emergy from the structure decreased, confirming the suitability of using environmentally sound building materials.

The housing unit that exhibited the best emergy-based performance has the second highest per dweller habitable space, the second lowest lot coverage percentage, the lowest net housing density, a moderate income level and it was the only one presenting a variety of housing types. Results suggest that, from the variables considered, the most important ones affecting the intensity of emergy utilization are per household income, per capita habitable space and, to a lesser extent, distance to downtown. In the analyzed residential units, while access to a higher level of income increased per capita emergy in all cases, increasing the availability of space per occupant did not result in a decrease of empower density after 50 square meters per person. Thus, emergy-based indicators may be a useful help for the set up of housing unit design guidelines aiming at the compliance of building regulations (dwelling size and housing typology) and to serve as complementary criteria for zoning distribution in urban master plans (housing units allocation).

Lastly, it is necessary to investigate more case studies to support or reject the apparent trends found in this study, including housing units with lower and higher development densities than those considered here. Future research avenues should take into consideration analyses at the scale of blocks and urban planning unities (neighborhoods and urban zoning) and methodologies for the quantification of consumption and travel patterns at the individual level and overall neighborhood consumption patterns. Future work should also include, in greater detail, space availability, housing typology, income level, distance to work and commercial centers, access to urban amenities and infrastructure, different weather conditions, among other aspects.

Acknowledgments: The authors would like to thank the anonymous reviewers for their careful reading and for their constructive comments and suggestions to improve the quality of the paper.

Author Contributions: Ricardo Enrique Vega-Azamar held the emergy synthesis analysis and managed the data and drew the manuscript up. Rabindranarth Romero-López held the system dynamics analysis of the built environment and helped with the manuscript draft. Norma Angélica Oropeza-García contributed to the mass and energy balance and helped with the manuscript draft. Mathias Glaus held the life cycle energy analysis and revised the manuscript. Robert Hausler held the environmental information management and revised the manuscript. Herlinda del Socorro Silva-Poot reviewed the housing typologies and other urban planning parameters and helped with the manuscript draft. All of the authors contributed to the work in this manuscript.

Conflicts of Interest: The authors declare no conflict of interest.

\section{References}

1. Cities and Climate Change: Global Report on Human Settlements, 1st ed. 2011. Available online: https: //unhabitat.org/books/cities-and-climate-change-global-report-on-human-settlements-2011/ (accessed on 18 April 2017).

2. Urbanization and Development. Emerging Futures. Available online: https://unhabitat.org/wp-content/ uploads/2014/03/WCR-\%20Full-Report-2016.pdf (accessed on 18 April 2017).

3. State of World Cities 2008/2009, Harmonious Cities, 1st ed. Available online: https://unhabitat.org/books / state-of-the-worlds-cities-20082009-harmonious-cities-2/ (accessed on 18 April 2017).

4. UNEP. Global Environmental Outlook 3 (Geo-3), 1st ed. Available online: http://www.grid.unep.ch/geo/ geo3/ (accessed on 18 April 2017).

5. Steemers, K. Energy and the city: Density, buildings and transport. Energy Build. 2003, 35, 3-14. [CrossRef]

6. Chen, S.; Chen, B. Network environ perspective for urban metabolism and carbon emissions: A case study of Vienna, Austria. Environ. Sci. Technol. 2012, 46, 4498-4506. [CrossRef] [PubMed]

7. Tukker, A.; Cohen, M.J.; Hubacek, K.; Mont, O. The impacts of household consumption and options for change. J. Ind. Ecol. 2010, 14, 13-30. [CrossRef] 
8. Newman, P.W.G.; Kenworthy, J.R. Gasoline consumption and cities. A comparison of U.S. Cities with a global survey. J. Am. Plan. Assoc. 1989, 55, 24-37. [CrossRef]

9. Bramley, G.; Power, S. Urban form and social sustainability: The role of density and housing type. Environ. Plan. B Plan. Des. 2009, 36, 30-48. [CrossRef]

10. Perkins, A.; Hamnett, S.P.; Zitto, R.; Trebilcock, D. Transport, housing and urban form: The life cycle energy consumption and emissions of city centre apartments compared with suburban dwellings. Urban Policy Res. 2009, 27, 377-396. [CrossRef]

11. CMHC. Greenhouse Gas Emissions from Urban Travel: Tool For Evaluating Neighbourhood Sustainability; Canada Mortgage and Housing Corporation: Ottawa, ON, Canada, 2000; p. 61.

12. Ramesh, T.; Prakash, R.; Shukla, K.K. Life cycle energy analysis of buildings: An overview. Energy Build. 2010, 42, 1592-1600. [CrossRef]

13. Jones, R.V.; Fuertes, A.; Lomas, K.J. The socio-economic, dwelling and appliance related factors affecting electricity consumption in domestic buildings. Renew. Sustain. Energy Rev. 2015, 43, 901-917. [CrossRef]

14. Decker, E.H.; Elliott, S.; Smith, F.A.; Blake, D.R.; Rowland, F.S. Energy and material flow through the urban ecosystem. Annu. Rev. Energy Environ. 2000, 25, 685-740. [CrossRef]

15. Hendriks, C.; Obernosterer, R.; Müller, D.; Kytzia, S.; Baccini, P.; Brunner, P.H. Material flow analysis: A tool to support environmental policy decision making. Case studies on the city of Vienna and the Swiss lowlands. Local Environ. 2000, 5, 311-328. [CrossRef]

16. Muñiz, I.; Galindo, A. Urban form and the ecological footprint of commuting. The case of Barcelona. Ecol. Econ. 2005, 55, 499-514. [CrossRef]

17. Rees, W.; Wackernagel, M. Urban ecological footprints: Why cities cannot be sustainable-And why they are a key to sustainability. Environ. Impact Assess. Rev. 1996, 16, 223-248. [CrossRef]

18. Norman, J.; MacLean, H.L.; Kennedy, C.A. Comparing high and low residential density: Life-cycle analysis of energy use and greenhouse gas emissions. J. Urban Plan. Dev. 2006, 132, 10-21. [CrossRef]

19. Treolar, G.; Love, P.; Holt, G. Using national input-output data for embodied energy analysis of individual residential buildings. Constr. Manag. Econ. 2001, 19, 49-61. [CrossRef]

20. Odum, H.T. Environmental Accounting: Emergy and Environmental Decision Making, 1st ed.; John Wiley: New York, NY, USA, 1996; p. 384.

21. Ascione, M.; Bargigli, S.; Campanella, L.; Ulgiati, S. Exploring an urban system's dependence on the environment as a source and a sink: The city of Rome (Italy) across space and time scales. ChemSusChem 2011, 4, 613-627. [CrossRef] [PubMed]

22. Huang, S.-L. Urban ecosystems, energetic hierarchies, and ecological economics of Taipei metropolis. J. Environ. Manag. 1998, 52, 39-51. [CrossRef]

23. Ascione, M.; Campanella, L.; Cherubini, F.; Ulgiati, S. Environmental driving forces of urban growth and development. An emergy-based assessment of the city of Rome, Italy. Landsc. Urban Plan. 2009, 93, 238-249. [CrossRef]

24. Lei, K.; Wang, Z.; Ton, S. Holistic emergy analysis of Macao. Ecol. Eng. 2008, 32, 30-43. [CrossRef]

25. Zhang, Y.; Yang, Z.; Liu, G.; Yu, X. Emergy analysis of the urban metabolism of Beijing. Ecol. Model. 2011, 222, 2377-2384. [CrossRef]

26. Vega-Azamar, R.E.; Glaus, M.; Hausler, R.; Oropeza-García, N.A.; Romero-López, R. An emergy analysis for urban environmental sustainability assessment, the island of Montreal, Canada. Landsc. Urban Plan. 2013, 18, 18-28. [CrossRef]

27. Brown, M.T.; Buranakarn, V. Emergy indices and ratios for sustainable material cycles and recycle options. Resour. Conserv. Recycl. 2003, 38, 1-22. [CrossRef]

28. Pulselli, R.M.; Simoncini, E.; Pulselli, F.M.; Bastianoni, S. Emergy analysis of building manufacturing, maintenance and use: Em-building indices to evaluate housing sustainability. Energy Build. 2007, 39, 620-628. [CrossRef]

29. Brown, M.T.; Vivas, B. Landscape development intensity index. Environ. Monit. Assess. 2005, 101, $289-309$. [CrossRef] [PubMed]

30. Hau, J.L.; Bakshi, B.R. Promise and problems of emergy analysis. Ecol. Model. 2004, 178, 215-225. [CrossRef]

31. Reza, B.; Sadiq, R.; Hewage, K. Emergy-based life cycle assessment (Em-LCA) of multi-unit and single-family residential buildings in Canada. Int. J. Sustain. Built Environ. 2014, 3, 207-224. [CrossRef] 
32. Reza, B.; Sadiq, R.; Hewage, K. Emergy-based life cycle assessment (Em-LCA) for sustainability appraisal of infrastructure systems: A case study on paved roads. Clean Technol. Environ. Policy 2014, 16, 251-266. [CrossRef]

33. Li, D.; Wang, R. Hybrid emergy-LCA (HEML) based metabolic evaluation of urban residential areas: The case of Beijing, China. Ecol. Complex. 2009, 6, 484-493. [CrossRef]

34. Codoban, N.; Kennedy, C.A. Metabolism of neighborhoods. J. Urban Plan. Dev. 2008, 134, 21-31. [CrossRef]

35. Pauleit, S.; Duhme, F. Assessing the environmental performance of land cover types for urban planning. Landsc. Urban Plan. 2000, 52, 1-20. [CrossRef]

36. Luederitza, C.; Langa, D.J.; Von Wehrden, H. A systematic review of guiding principles for sustainable urban neighborhood development. Landsc. Urban Plan. 2013, 118, 40-52. [CrossRef]

37. Kennedy, C.; Pincetl, S.; Bunje, P. The study of urban metabolism and its applications to urban planning and design. Environ. Pollut. 2011, 159, 1965-1973. [CrossRef] [PubMed]

38. ISQ. Bulletin Statistique Régional Montréal, Édition 2015 (Montreal Regional Statistical Bulletin, 2015 Edition). Available online: http:/ /www.stat.gouv.qc.ca/statistiques/profils/bulletins/2015/06-Montreal. pdf (accessed on 18 April 2017).

39. City of Montreal. The Montreal Economy. Available online: http://www.montreal2025.com/decouvrir_ economie.php?lang=en (accessed on 27 October 2011).

40. Communauté Métropolitaine de Montréal. Les Forms D’habitat et la Planification des Densités Résidentielles (Housing Types and Planning of Residential Densities). Available online: http:/ / projet.pmad.ca/fileadmin/ user_upload/pmad2011/documentation/20110309_formesHabitat.pdf (accessed on 13 February 2012).

41. Brown, M.T.; Ulgiati, S. Emergy analysis and environmental accounting. In Encyclopedia of Energy; Cleveland, C.J., Ed.; Elsevier Academic Press: Oxford, UK, 2004; pp. 329-354.

42. Odum, H.T.; Brown, M.T.; Brandt-Williams, S.L. Handbook of Emergy Evaluation. Folio \#1. Introduction and Global Budget. Available online: http:/ /www.cep.ees.ufl.edu/emergy/documents/folios/Folio_01.pdf (accessed on 18 April 2017).

43. Odum, H.T. Handbook of Emergy Evaluation. Folio \#2. Emergy of Global Processes. 2000. Available online: http:/ / www.cep.ees.ufl.edu/emergy/documents/folios/Folio_02.pdf (accessed on 18 April 2017).

44. Brandt-Williams, S.L. Handbook of Emergy Evaluation. Folio \#4. Emergy of Florida Agriculture. 2002. Available online: http://www.cep.ees.ufl.edu/emergy/documents/folios/Folio_04.pdf (accessed on 18 April 2017).

45. Brown, M.T.; Bardi, E. Handbook of Emergy Evaluation. Folio \#3. Emergy of Ecosystems. Available online: http:/ / www.cep.ees.ufl.edu/emergy/documents/folios/Folio_03.pdf (accessed on 18 April 2017).

46. Kangas, P.C. Handbook of Emergy Evaluation. Folio \#5. Emergy of Landforms. Available online: http: //www.cep.ees.ufl.edu/emergy/documents/folios/Folio_05.pdf (accessed on 18 April 2017).

47. Buckley, M.; Halsall, R.; Vollering, B.; Webber, D. Considering Sustainability in the Selection of Structural Systems. Available online: http://livebuilding.queensu.ca/files/Considering\%20Sustainability. pdf (accessed on 22 June 2012).

48. Bastos, J.; Batterman, S.A.; Freire, F. Significance of mobiity in the life-cycle assessment of buildings. Build. Res. Inf. 2016, 44, 376-393. [CrossRef]

49. Campbell, D.E.; Brandt-Williams, S.L.; Meisch, M.E.A. Environmental Accounting Using Emergy: Evaluation of the State of West Virginia. Available online: http://www.epa.gov/nheerl/publications/ files/wvevaluationposted.pdf (accessed on 26 September 2010).

50. Brown, M.T.; Ulgiati, S. Emergy-based indices and ratios to evaluate sustainability: Monitoring economies and technology towards environmentally sound innovation. Ecol. Eng. 1997, 9, 51-69. [CrossRef]

51. Huang, S.-L.; Chen, C.W. Theory of urban energetics and mechanisms of urban development. Ecol. Model. 2005, 189, 49-71. [CrossRef]

52. Pulselli, R.M. Integrating emergy evaluation and geographic information systems for monitoring resource use in the Abruzzo region (Italy). J. Environ. Manag. 2010, 91, 2349-2357. [CrossRef] [PubMed]

53. Bastianoni, S.; Marchettini, N.; Niccolucci, V.; Pulselli, F.M. Environmental accounting for the lagoon of Venice and the case of fishing. Ann. Chim. 2005, 95, 143-152. [CrossRef]

54. Bastianoni, S.; Campbell, D.E.; Ridolfi, R.; Pulselli, F.M. The solar transformity of petroleum fuels. Ecol. Model. 2009, 220, 238-249. [CrossRef] 
55. Brown, M.T.; Ulgiati, S. Emergy evaluations and environmental loading of electricity production systems. J. Clean. Prod. 2002, 10, 321-334. [CrossRef]

56. Castellini, C.; Bastianoni, S.; Grani, C.; Dal Bisco, A.; Brunetti, M. Sustainability of poultry production using the emergy approach: Comparison of conventional and organic rearing systems. Agric. Ecosyst. Environ. 2006, 114, 343-350. [CrossRef]

57. Brown, M.T.; Ulgiati, S. Energy quality, emergy and transformity: H.T. Odum's contributions to quantifying and understanding systems. Ecol. Eng. 2004, 178, 201-213. [CrossRef]

58. Le Corre, O. Emergy, 1st ed.; ISTE Press-Elsevier: Oxford, UK, 2016; p. 178.

59. Leloup, X.; Séraphin, I. Étude Post Occupation de Projets Résidentiels Pour Familles en Milieu Urbain Dense (Post Occupancy Study of Residential Projects for Families in Dense Urban Environment), 1st ed.; INRS Institut National de la Recherche Scientifique: Montreal, QC, Canada, 2009; p. 120.

60. Canada, S. Consumer Price Indexes, Historical Summary. Available online: http://www.statcan.gc.ca/ tables-tableaux/sum-som/101/cst01/econ46a-eng.htm (accessed on 12 July 2012).

61. National Aeronautics and Space Administration. Insolation levels. Surface meteorology and solar energy data set. In Proceedings of the Rise and Shine 2000, the 26th Annual Conference of the Solar Energy Society of Canada Inc. and Solar, Halifax, NS, Canada, 21-24 October 2000.

62. Canada, E. Canadian Climate Normals or Averages 1971-2000. Montreal Trudeau International Airport Station. Available online: http://climate.weatheroffice.gc.ca/climate_normals/results_e.html?stnID= 5415\&lang $=\mathrm{e} \& \mathrm{dCode}=1 \&$ StationName $=$ MONTREAL\&SearchType $=$ Contains $\&$ province $=$ ALL \&provBut $=$ \&month1=0\&month2=12 (accessed on 22 November 2011).

63. Davies, J.H.; Davies, D.R. Earth's surface heat. Solid Earth 2010, 1, 15-24. [CrossRef]

64. Canada, S. Food Statistics 2008; Statistics Canada: Ottawa, ON, Canada, 2009; p. 44.

65. Montreal, C. Profils des 58 Districts Électoraux de la Ville de Montréal, Édition 2009 (City of Montreal's 58 Electoral Districts Profiles, 2009 Edition). Available online: https://ville.montreal.qc.ca/pls/portal/docs/ PAGE/MTL_STATS_FR/MEDIA/DOCUMENTS/58\%20DISTRICTS\%20\%C9LECTORAUX_2009.PDF (accessed on 18 April 2017).

66. City of Montreal. Profils Économiques des Arrondissements. Montréal en Statistiques. Par Territoire. Arrondissements de Montréal. (Economic Profiles of Boroughs. Montreal in Statisics. By Territory. Montreal's Boroughs). Available online: http://ville.montreal.qc.ca/portal/page?_pageid=6897,67845597\&_dad= portal\&_schema=PORTAL (accessed on 4 May 2012).

67. City of Montreal. Eau Potable Traitée, Agglomération de Montréal, Moyenne Annuelle (Treated Drinking Water, Agglomeration of Montreal, Annual Average). Available online: http://ville.montreal.qc.ca/portal/ page?_pageid=6897,67889708\&_dad=portal\&_schema=PORTAL (accessed on 29 March 2011). (In French)

68. CMHC. Analysis of the annual energy and water consumption of apartment buildings in the cmhc histar database. CMHC's Tech. Ser. Res. Highlights 2001, 142, 1-4.

69. CWC. Energy and the environment in residential construction. Canadian Wood Council. Sustain. Build. Ser. No 2004, 1, 15.

70. Baouendi, R.; Zmeureanu, R.; Bradley, B. Energy and emission estimator: A prototype tool for designing canadian houses. J. Archit. Eng. 2005, 11, 50-59. [CrossRef]

71. Canada, S. Households and the Environment: Energy Use 2007; Statistics Canada: Ottawa, ON, Canada, 2010; p. 39.

72. Liu, R. Energy Consumption and Energy Intensity in Multi-Unit Residential Buildings in Canada. Available online: http:/ / www.cbeedac.com/publications/documents/MURBsrp04.pdf (accessed on 12 March 2012).

73. Agence Métropolitaine de Transport. Mobilité des Personnes dans la Région de Montréal Enquête Origine-Destination 2008. (Mobility of people in the Montreal area origin-destination survey 2008; data processing: R.E Vega-Azamar). Available online: https://www.amt.qc.ca/Media/Default/pdf/section8/ mobilite-des-personnes-dans-la-region-de-montreal.pdf (accessed on 26 January 2015).

74. NRC-OEE. Fuel Consumption Guide 2008; Natural Resources Canada: Ottawa, ON, Canada, 2007; p. 65.

75. Páez, A.; Mercado, R.G.; Farber, S.; Morency, C.; Roorda, M. Accessibility to health care facilities in Montreal island: An application of relative accessibility indicators from the perspective of senior and non-senior residents. Int. J. Health Geogr. 2010, 9, 1-9. [CrossRef] [PubMed] 
76. Bonenfant, R.R.J. How to Estimate the Cost of Structural Steel. American Society of Professional Estimators' Technical Paper. Estimating Today. January 2009. Available online: http:/ /www.aspenational.org/userfiles/ file/Technical\%20Papers/2009/TechPaper_January2009.pdf (accessed on 5 June 2012).

77. Farnsworth, E. How to Estimate the Cost of a Timber Framed Structure. American Society of Professional Estimators. Technical Paper. Estimating Today. December 2010. Available online: http:/ /www.aspenational. org/userfiles/file/Technical\%20Papers/2010/ET-2010December-TechPaper.pdf (accessed on 3 July 2012).

78. Nocus, S.F. How to Estimate the Cost of Load Bearing Wood Framed Walls. American Society of Professional Estimators' Technical Paper. Estimating Today. April 2009. Available online: http:/ /www.aspenational.org/ userfiles / file/Technical\%20Papers/2009/TechPaper_April2009.pdf (accessed on 3 July 2012).

79. Schlesier, B.E. How to Estimate the Cost of Concrete Construction. American Society of Professional Estimators' Technical Paper. Estimating Today. March 2010. Available online: http:/ /www.aspenational.org/ userfiles/file/Technical\%20Papers/2010/TechPaper_March2010.pdf (accessed on 3 July 2012).

80. City of Montreal. Portrait 2010 des Matiéres Résiduelles de L'agglomération de Montréal (2010 Portrait of Municipal Solid Wastes of the Agglomeration of Montreal). Available online: http://ville.montreal.qc.ca/pls/portal/docs/PAGE/ENVIRO_FR/MEDIA/DOCUMENTS/PORTRAIT_ MATIERES_RESIDUELLES2010.PDF (accessed on 28 September 2012). (In French)

81. Purenne, P. Rapport Annuel 2008. Analyse de la Qualité des Eaux Brutes et de L'eau Traitée à la Station D'épuration et Évaluation du Rendement des Installations (Annual Report 2008. ANALYSIS of the Quality of Raw and Treated Water at the Treatment Plant and Evaluation of the Facilities' Performance). Available online: http://ville.montreal.qc.ca/pls/portal/docs/PAGE/EAU_FR/MEDIA/DOCUMENTS/AN08STAF. PDF (accessed on 6 April 2011). (In French)

82. Vega-Azamar, R.E.; Romero-López, R.; Glaus, M.; Oropeza-García, N.A.; Hausler, R. Sustainability assessment of the residential land use in seven boroughs of the island of Montreal, Canada. Sustainability 2015, 7, 2454-2472. [CrossRef]

83. Brown, M.T.; Ulgiati, S. Emergy measures of carrying capacity to evaluate economic investments. Popul. Environ. 2001, 22, 471-501. [CrossRef]

84. Cai, Z.F.; Zhang, L.X.; Zhang, B.; Chen, Z.M. Emergy-based analysis of Beijing-Tianjin-Tangshan region in China. Commun. Nonlinear Sci. Numer. Simul. 2009, 14, 4319-4331. [CrossRef] 